\title{
Knowledge of Farmers about Pest Management in Maize Crop in Panchmahals District
}

\author{
C. B. Damor ${ }^{1 *}$, D. M. Rathod ${ }^{2}$, G. D. Hadiya ${ }^{1}$ and R. G. Machhar ${ }^{1}$ \\ ${ }^{1}$ Agricultural Research Station, Anand Agricultural University, Derol, India \\ ${ }^{2}$ Main Maize Research Station, Anand Agricultural University, Godhra, India \\ *Corresponding author
}

\begin{abstract}
A B S T R A C T
\section{Keywords}

Level of

Knowledge, Pest

management, Maize

Article Info

Accepted:

16 November 2020

Available Online:

10 December 2020

The study was conducted to know the level of knowledge of the maize farmers regarding pest management of maize crop in Panchmahals district. Gujarat state has 33 districts and out of these Panchmahal district purposively selected for this study. Panchmahals district comprises seven talukas out of them three talukas viz. Godhra, Kalol, and Halol, were selected purposively. There are four villages were selected randomly. After selection of villages 10 maize farmers from each village were selected randomly, Thus, in all 120 maize farmers were constitute the sample for this investigation. The data of this study were collected by arranging personal interview. Vast majority of the maize farmers had knowledge about manual weed management (95.00 per cent). Majority of maize farmers had knowledge about fertilizer management in FYM (70.00 per cent), university recommended improved varieties (68.33 per cent), seed rate and time of sowing(65.83 per cent), knowledge of occurrence of Helicoverpa armigera (64.16 per cent), knowledge of occurrence of hairy caterpillar (62.50 per cent), seed treatment as well as knowledge of occurrence of aphid (60.83 per cent) and spacing in composite varieties (60.00 per cent).
\end{abstract}

\section{Introduction}

Maize (Zea mays L.) is one of the most versatile emerging crop shaving wider adaptability under varied agro-climatic conditions. Globally, maize is known as queen of cereals because it has the highest genetic yield potential among the cereals. It is cultivated on nearly $190 \mathrm{~m}$ ha in about 165 countries having wider diversity of soil, climate, biodiversity and management practices that contributes $39 \%$ in the global grain production. The United States of
America (USA) is the largest producer of maize contributes nearly $36 \%$ of the total production in the world and maize is the driver of the US economy (Annonymous). In India, Maize is grown throughout the year. It is predominantly a kharif crop with 85 per cent of the area under cultivation in the season. Maize is grown as main crop in Panchmahals districts of Gujarat state and it is cultivated in approximately 2.70 lakh hectare area in kharif season. Research scientists, extension workers and farmers have responsibilities to maximize the production 
and productivity of maize in per unit area. The productivity of maize in Gujarat is 1478 $\mathrm{kg} / \mathrm{h}$ and national average productivity is $2965 \mathrm{~kg} / \mathrm{ha}$ (ICAR- Indian Institute of Maize Research 2018-19). The low productivity in maize was due to lack of scientific cultivation knowledge, poor nutrient management and lack of knowledge on insect pests and disease management. Hence, the experiment was conducted to study knowledge of farmers about pest management in maize crop in Panchmahals district.

The main objectives of this include to know the level of knowledge of the maize farmers regarding pest management

\section{Materials and Methods}

Gujarat state has 33 districts and out of these Panchmahal district purposively selected for this study. Panchmahals district comprises seven talukas out of these three talukas viz., Godhra, Kalol and Halol were selected purposively. There are four villages were selected randomly. After selection of villages 10 maize farmers from each village were selected randomly, Thus, in all 120 maize farmers were constitute the sample for this investigation. The data of this study were collected by arranging personal interview. The data was analyzed and interpreted with frequency and percentage.

\section{Results and Discussion}

The main purpose of the present investigation was to study the level of knowledge of the maize farmers regarding pest management in Panchmahals district. The results are presented as under.

The data in table 1 indicated that vast majority of the maize farmers had knowledge about manual weed management (95.00 per cent). Majority of maize farmers had knowledge about fertilizer management in FYM (70.00 per cent), university recommended varieties (68.33 per cent), seed rate and time of sowing (65.83 per cent), knowledge of occurrence of Helicoverpa armigera (64.16 per cent), knowledge of occurrence of hairy caterpillar (62.50 per cent), seed treatment and knowledge of occurrence of aphid (60.83 per cent), spacing in composite varieties (60.00 per cent).

Table.1 Distribution of maize farmers according to their knowledge level $(n=120)$

\begin{tabular}{|c|l|c|c|}
\hline Sr. No & \multicolumn{1}{|c|}{ Particulars } & Frequency & Percentage \\
\hline 1. & Time of sowing & 79 & 65.83 \\
\hline 2. & Improved varieties & & \\
\hline & \multicolumn{1}{|c|}{ University recommended } & 82 & 68.33 \\
\hline 3. & Seed rate & 78 & 65.00 \\
\hline 4. & Seed treatment & 79 & 65.83 \\
\hline 5. & Spacing & 73 & 60.83 \\
\hline & Composite & 72 & 60.00 \\
\hline & Hybrid & 69 & 57.50 \\
\hline 6. & Fertilizer Management & & \\
\hline & 1. FYM & & 70.00 \\
\hline & 2. Chemical fertilizers dose & \\
\hline
\end{tabular}




\begin{tabular}{|c|c|c|c|}
\hline & Composite & & \\
\hline & Recommended dose of $\mathrm{N}_{2}$ & 68 & 56.66 \\
\hline & Recommended dose of $\mathrm{P}_{2} \mathrm{O}_{5}$ & 55 & 45.83 \\
\hline & Recommended dose of $\mathrm{K}_{2} \mathrm{O}$ & 00 & 00.00 \\
\hline & Hybrid & & \\
\hline & Recommended dose of $\mathrm{N}_{2}$ & 54 & 45.00 \\
\hline & Recommended dose of $\mathrm{P}_{2} \mathrm{O}_{5}$ & 50 & 41.67 \\
\hline & Recommended dose of $\mathrm{K}_{2} \mathrm{O}$ & 00 & 00.00 \\
\hline 7. & $\begin{array}{l}\text { Fertilizer requirement at different } \\
\text { stage }\end{array}$ & 61 & 50.83 \\
\hline \multirow[t]{17}{*}{8.} & Insect control in Maize & & \\
\hline & 1. Maize stem borer & & \\
\hline & $\begin{array}{l}\text { Knowledge of occurrence of } \\
\text { Maize stem borer }\end{array}$ & 81 & 67.50 \\
\hline & $\begin{array}{l}\text { Knowledge of name of } \\
\text { chemical to control Maize stem } \\
\text { borer }\end{array}$ & 62 & 51.66 \\
\hline & $\begin{array}{l}\text { Knowledge of recommended } \\
\text { dose of chemical to control } \\
\text { Maize stem borer }\end{array}$ & 49 & 40.83 \\
\hline & 2. Helicoverpa armigera & & \\
\hline & $\begin{array}{l}\text { Knowledge of occurrence of } \\
\text { Helicoverpa armigera }\end{array}$ & 77 & 64.16 \\
\hline & $\begin{array}{l}\text { Knowledge of name of } \\
\text { chemical to } \\
\text { Helicoverpa } \\
\text { armigera }\end{array}$ & 59 & 49.16 \\
\hline & $\begin{array}{l}\text { Knowledge of recommended } \\
\text { dose of chemical to control } \\
\text { Helicoverpa armigera }\end{array}$ & 37 & 30.83 \\
\hline & 3. Fall armyworm & & \\
\hline & $\begin{array}{l}\text { Knowledge of occurrence of } \\
\text { Fall armyworm }\end{array}$ & 69 & 57.50 \\
\hline & $\begin{array}{l}\text { Knowledge of name of } \\
\text { chemical to control Fall } \\
\text { armyworm }\end{array}$ & 51 & 42.50 \\
\hline & $\begin{array}{l}\text { Knowledge of recommended } \\
\text { dose of chemical to control Fall } \\
\text { armyworm }\end{array}$ & 34 & 28.33 \\
\hline & 4. Hairy caterpillar & & \\
\hline & $\begin{array}{l}\text { Knowledge of occurrence of } \\
\text { Hairy caterpillar }\end{array}$ & 75 & 62.50 \\
\hline & $\begin{array}{l}\text { Knowledge of name of } \\
\text { chemical to control Hairy } \\
\text { caterpillar }\end{array}$ & 59 & 49.16 \\
\hline & Knowledge of recommended & 28 & 23.33 \\
\hline
\end{tabular}




\begin{tabular}{|c|c|c|c|}
\hline & $\begin{array}{l}\text { dose of chemical to control } \\
\text { Hairy caterpillar }\end{array}$ & & \\
\hline & 5. Aphid & & \\
\hline & $\begin{array}{l}\text { Knowledge of occurrence of } \\
\text { Aphid }\end{array}$ & 73 & 60.83 \\
\hline & $\begin{array}{l}\text { Knowledge of name of } \\
\text { chemical to control Aphid }\end{array}$ & 57 & 47.50 \\
\hline & $\begin{array}{l}\text { Knowledge of recommended } \\
\text { dose of chemical to control } \\
\text { Aphid }\end{array}$ & 39 & 32.50 \\
\hline \multirow[t]{9}{*}{9.} & Disease name & & \\
\hline & 1. Maydis leaf blight (MLB) & & \\
\hline & $\begin{array}{l}\text { Knowledge of occurrence of } \\
\text { Maydis leaf blight }\end{array}$ & 64 & 53.33 \\
\hline & $\begin{array}{l}\text { Knowledge of name of chemical } \\
\text { to control Maydis leaf blight }\end{array}$ & 37 & 30.83 \\
\hline & $\begin{array}{l}\text { Knowledge of recommended } \\
\text { dose of chemical to control } \\
\text { Maydis leaf blight }\end{array}$ & 25 & 20.83 \\
\hline & 2. Late wilt & & \\
\hline & $\begin{array}{l}\text { Knowledge of occurrence of Late } \\
\text { wilt }\end{array}$ & 71 & 59.16 \\
\hline & $\begin{array}{l}\text { Knowledge of name of chemical } \\
\text { to control Late wilt }\end{array}$ & 53 & 44.16 \\
\hline & $\begin{array}{l}\text { Knowledge of recommended } \\
\text { dose of chemical to control Late } \\
\text { wilt }\end{array}$ & 32 & 26.67 \\
\hline \multirow[t]{4}{*}{10.} & Weed management & & \\
\hline & Manual & 114 & 95.00 \\
\hline & Name of herbicide & 56 & 46.66 \\
\hline & Recommended dose & 35 & 29.16 \\
\hline
\end{tabular}

More than half of maize farmers had knowledge of occurrence of late wilt disease (59.16 per cent), knowledge of occurrence of fall armyworm (57.60 per cent), spacing in hybrid verities (57.33 per cent), recommended dose of $\mathrm{N}_{2}$ (56.66 per cent), knowledge of occurrence of maydis leaf blight (53.33 per cent), name of chemical to control stem borer (51.66 per cent), fertilizer requirement at different stage (50.83 per cent).

Less than half of maize farmers had knowledge about name of chemical to control Helicoverpa armigera (49.16 per cent), name of chemical to control fall armyworm (47.50 per cent), herbicide (46.66 per cent), recommended dose of $\mathrm{P}_{2} \mathrm{O}_{5}$ in composite varieties (45.83 per cent), for hybrid varieties recommended dose of $\mathrm{N}_{2}$ (45.00 per cent), name of chemical to control late wilt (44.16 per cent), name of chemical to control fall armyworm (42.50 per cent), recommended dose of $\mathrm{P}_{2} \mathrm{O}_{5}$ in hybrid varieties (41.67 per cent), knowledge of recommended dose of 
chemical to control maize stem borer ( 40.83 per cent) and name of chemical to control aphid (37.50 per cent).

Slightly greater than one third of maize farmer had knowledge about recommended dose of chemical to control aphid (34.16 per cent), name of chemical to control maydis leaf blight (30.83 per cent), recommended dose of herbicide (29.16 per cent), recommended dose of chemical to control fall armyworm (28.33 per cent), recommended dose of chemical to control late wilt (26.67 per cent). Slightly less than one fourth recommended dose of chemical to control fall armyworm (23.33 per cent) and recommended dose of chemical to control maydis leaf blight (20.83 per cent).

In conclusion the vast majority of the maize farmers belonged to middle to young age group, more than half of maize farmers had secondary to higher secondary level of education, high level of extension contact, medium level of mass media exposure and small to medium size of land holding. Vast majority of the maize farmers had knowledge about manual weed management, majority of maize farmers had knowledge about fertilizer management in FYM, university recommended improved varieties, seed rate and time of sowing, knowledge of occurrence of Helicoverpa armigera and hairy caterpillar, seed treatment as well as knowledge of occurrence of aphid and spacing in composite varieties.

\section{References}

Anonymous (http://agriexchange.apeda.gov. in)

Kumar, D., Ram, J., Bhati, D. S. and Dangi, K. L. 2011. Knowledge of Improved Castor Production Technology among Tribal and Non-Tribal Farmers of Sirohi district of Rajasthan. Journal of Progressive Agriculture. 2(3): 62-64.

Pandya, C. D., Bhatt, S. T. and Chauhan, N. M. 2013. Knowledge and adoption level of farmers about scientific cultivation of okra in Tapi district. Gujarat Journal of Extension Education. 24:102-104.

Parmar P. B. 2006. A study on knowledge and extent of adoption of recommended paddy production technology the paddy growers in Khambhat taluka of Anand district. M.Sc (Agri) thesis (Unpub.) Anand Agricultural University, Anand.

\section{How to cite this article:}

Damor, C. B., D. M. Rathod, G. D. Hadiya and Machhar, R. G. 2020. Knowledge of Farmers about Pest Management in Maize Crop in Panchmahals District. Int.J.Curr.Microbiol.App.Sci. 9(12): 2138-2142. doi: https://doi.org/10.20546/ijcmas.2020.912.251 